Article

\title{
The Transformation by Catalysis of Prebiotic Chemical Systems to Useful Biochemicals: A Perspective Based on IR Spectroscopy of the Primary Chemicals II. Catalysis and the Building of RNA
}

\author{
Ragnar Larsson 1,*, Abdul Malek ${ }^{2}$ (D) and Ingemar Odenbrand ${ }^{1, *}$ \\ 1 Department of Chemical Engineering, University of Lund, Box 124, SE 22100 Lund, Sweden \\ 2 Technologie DMI, 980 Rue Robert Brossard, Quebec, PQ 14X 1C9, Canada, abdulmalek@qc.aibn.com \\ * Correspondence: ragnar-larsson@telia.com or ragnar.larsson@chemeng.lth.se (R.L.); \\ ingemar.odenbrand@chemeng.lth.se (I.O.)
}

Received: 24 February 2020; Accepted: 12 June 2020; Published: 8 July 2020

\begin{abstract}
Having found that carbonyl sulfide (COS), works well as a catalyst in the transformation of amino acids to polypeptides, we have now tested COS as a catalyst also for the formation of substances that might be thought of as partners in the building of RNA. The model used was selective energy transfer (SET). This model implies that a certain number of vibrational quanta are donated from the catalyst system and a corresponding number of quanta of the reactant accept the energy thus transferred. In this way, we found that carbonyl sulfide, COS, was a perfect catalyst for combining, first, five molecules of formaldehyde to form one molecule of ribose, and next, five molecules of hydrogen cyanide, $\mathrm{HCN}$, to form one molecule of adenine, one of the nucleobases of RNA. However, beyond this, we found that COS was a perfect catalyst for precisely all reactions, needed to build the RNA, ribonucleic acid.
\end{abstract}

Keywords: selective energy transfer (SET); RNA; ribonucleic acid; nucleobases; vibrational resonance; quanta; catalysis; synthesis

\section{Introduction}

In our previous paper [1] we have treated reactions involving amino acids and the formation of peptide bonds by catalysts such as carbonyl sulfide (COS) or others, like $\mathrm{Fe}(\mathrm{CN})_{6}{ }^{4-}$ and cyanamide $\left(\mathrm{H}_{2} \mathrm{~N}-\mathrm{CN}\right)$, finding that a resonance effect described by the selective energy transfer (SET) model works quite satisfactorily. In this paper, we will concentrate on the formation of RNA, ribonucleic acid, which is built from units such as $\mathrm{PO}_{4}{ }^{3-}$, ribose and four kinds of nucleobases, i.e., adenine, cytosine, guanine, and uracil (Figure 1). The nucleotides, thus formed, are combined to a long chain with the phosphate ions and the sugar ribose, as coupling units. The reactions that result in these polymeric systems are greatly dependent on effective catalysts and we will also here apply the theory of "selective energy transfer" (SET), described in previous papers, e.g., [2-4]. The basic concept of SET is that the catalyst does have a vibration frequency that is equal to-or nearly equal to- that of the vibration in the reacting molecule that is supposed to lead to reaction. This means that a state of resonance will be established between the two systems: catalyst and reactant. When the systems are coupled in such a way, the 'energy transfer' is carried out by transfer of one or several vibrational quanta, from catalyst to reactant, and the rate of the reaction is set by the rate of energy transfer [5]. 


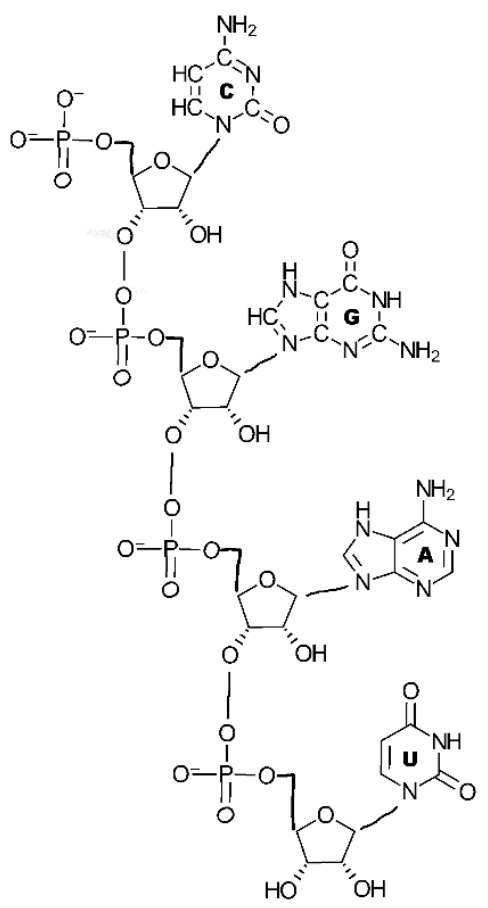

Figure 1. A fraction of the long chain of RNA, ribonucleic acid, showing the 'back-bone' of phosphate groups and ribose. The ribose binds to the phosphate in two positions (C (3) and C (5)) and to one out of four nucleobases in the C (1) position.

\section{The SET Model Exemplified}

This model of catalysis was originally initiated from observations that the activation energies of catalytic reactions varied in a stepwise fashion [6]. We will in the following exemplify the function of SET by considering the formation of the primary constituents of RNA, i.e., the formation of ribose and the four nucleobases. By the action of the catalyst, the units that are building the various parts of RNA are accepting quanta from the COS molecule. In this way they reach - stepwise - their ability to react.

Furthermore, SET will be used to illustrate the binding of these nucleobases, as well as phosphate groups, towards the ribose structure In Figure 1, one can see how a chain of ribose molecules is formed by binding to two groups of phosphates using two different sites on each ribose molecule.

On the other side of this chain, four different nucleobases are bonded, one for each of the ribose molecules. By variation of the internal positions of the nucleobases a long chain is shaped, with a multitude of properties defined by this ordering and the physical parameters of the four nucleobases.

We will in the following exemplify the function of SET by considering the formation of the primary constituents of RNA, i.e., the formation of ribose and the four nucleobases. Furthermore, SET will be used to illustrate the binding of these nucleobases, as well as phosphate groups, towards the ribose structure.

\section{The Formation of the Constituents of RNA}

The existence of the relatively complicated molecules indicated in Figure 1 must not be taken for granted. In the conditions of an early atmosphere, one must ask from which simpler molecules they were formed. Further, is this formation possible to describe by the SET model?

In this context, we will introduce carbonyl sulfide, COS, as the catalyst. This gaseous substance is characterized by one very strong IR absorption band, at $2079 \mathrm{~cm}^{-1}$, [7], and consequently (e.g., p. 20, Formula I. 48 in [8]), also by a strong emission band of the same frequency. 
Hence, in order for the SET model to work properly, the frequency of the accepting (reacting) vibration should be a factor $\mathrm{x}$ of $2079 \mathrm{~cm}^{-1}$. Here $\mathrm{x}$ could be $0.5,1,2,3$ etc., but also 1.5, 1.3333 or 1.25 , etc.

As an example, if $x=2$, or in other words, $v$ (reactant) $=2 \times 2079 \mathrm{~cm}^{-1}$, it means that one quantum of the reacting molecule needs two quanta from the catalyst to achieve a reaction.

Similarly, if $x=1.3333, v$ (reactant $)=4 / 3 \times 2079 \mathrm{~cm}^{-1}$, or $v$ reactant $/ \omega$ catalyst $=4: 3$. This means that 4 quanta of the catalyst match 3 quanta that will produce a reaction. To specify the relations between quanta of catalyst and reactant, one can form the expression 2073/v (reactant) that we call the resonance condition (RC). The use of this quantity to describe which vibration of the reactant that is nearest a resonance situation for a given catalyst is exemplified, e.g., in Chapter 2.1 to follow.

SET has shown itself useful in many other cases. As an example, we can state that it is possible to calculate the so called "isokinetic temperature" [9].

In a series of hydrodechlorinations of chlorobenzene over Ni but with varying support, we observed that the Arrhenius lines were crossing each other at one temperature, the isokinetic temperature, $669 \pm 2 \mathrm{~K}$. The theory of SET made it possible to calculate the exact value to Tiso $=669.2 \mathrm{~K}$ in perfect agreement with the experimental value, mentioned above [10]. This result strongly points to the usefulness of SET.

\section{A SET Approach to the Synthesis of Ribose}

As shown in Figure 1, the basis of the RNA structure is the ribose link. We will now discuss the potential route of synthesis of this substance, starting from the simplest example of a compound containing carbon, oxygen, and hydrogen, namely, $\mathrm{HCHO}$, formaldehyde. This simple molecule must expose a similarly simple IR spectrum. The Table 1 gives the data from the investigations of Herzberg, (table 76 in [10]), characterizing the $4 \times 3-6=6$ normal vibrations as shown in Figure 2 . Furthermore, it is in (table 42 of [10]), that one finds the exact value, $2079 \mathrm{~cm}^{-1}$, of the $v 3$ vibration of the catalyst COS.
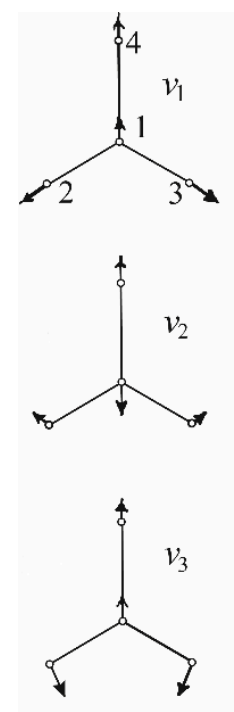
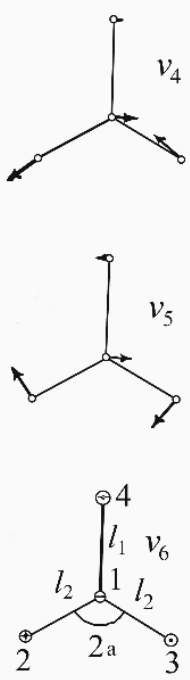

Figure 2. Molecular vibrations of, e.g., $\mathrm{H}_{2} \mathrm{CO}$.

The first point of our discussion is to find, if there exists, among the available data, a pronounced resonance condition, $\mathrm{RC}$, i.e., $2079 / \mathrm{v} \mathrm{cm} \mathrm{cm}^{-1}$. With 'pronounced' we mean a $v$-value that gives a small value of $\Delta$ (the difference between 2079 and $v \mathrm{~cm}^{-1}$ ), such as is explained as follows: full resonance occurs when the frequencies of catalyst and reactant are exactly equal. The relative difference between the ratio $\omega / v$ and the nearest ratio of small integers, we designate as $\Delta \%$. Here $\omega$ is the frequency of 
the catalyst and $v$ is the frequency of the reactant, e.g., in the row for $v 2$ of Table 1 , the closest ratio of $\mathrm{RC}$ is $1.200=6: 5$.

Of the three items in the Table 1 that show $\Delta$-values less than $1 \%, v 1$ is a fully symmetric vibration which does not relates to a strong distortion of the molecule, and the existence of the one named $2 \vee 6$ has been strongly doubted (foot note 96 in [10]). However, the $v 2$ vibration has a very strong IR absorption/emission and, furthermore, it is mainly a $\mathrm{C}=\mathrm{O}$ vibration where 5 quanta of the $2079 \mathrm{~cm}^{-1}$ vibration contribute energy to 6 quanta of the $1743.6 \mathrm{~cm}^{-1}$ vibration. This means, that at the extreme points of the vibration, i.e., when the adsorption of quanta from the catalyst is at its maximum, the $2 p-2 p$ interaction is considerably weakened and the bond between the carbon and the oxygen is close to a single bond.

Table 1. Treatment of observed vibrations of $\mathrm{H}_{2} \mathrm{CO}$.

\begin{tabular}{ccccc}
\hline Assignment & $\boldsymbol{v \mathbf { ~ c m } ^ { - 1 }}$ & R.C. $=\mathbf{2 0 7 9 / v}$ & $\boldsymbol{\Delta} \%$ & $\boldsymbol{\omega} / \boldsymbol{v}$ \\
\hline$v 6$ & 1167 & 1.781 & 3.1 & $7: 4$ \\
\hline$v 5$ & 1280 & 1.624 & 4.3 & $5: 3$ \\
\hline$v 3$ & 1503 & 1.383 & 5.0 & $4: 3$ \\
\hline$v 2$ & 1743.6 & 1.192 & 0.67 & $6: 5$ \\
\hline $2 v 6$ & 2081 & - & 0.1 & $1: 1$ \\
\hline$v 1$ & 2780 & 0.748 & 0.27 & $3: 4$ \\
\hline$v 4$ & 2874 & 0.723 & 7.2 & $3: 4$ \\
\hline $2 v 3$ & 2973 & 0.699 & 6.9 & $2: 3$ \\
\hline
\end{tabular}

We designate this state as $\mathrm{C}^{*}-\mathrm{O}^{*}$, in Scheme 1 , where the asterisk indicates (almost) half-filled $2 p$ orbitals. In Scheme 1 we now illustrate the reaction steps that will follow from the excitation of formaldehyde molecules via the catalyst COS.

$$
\begin{gathered}
\mathrm{O}=\mathrm{CH}_{2}=>\mathrm{O}^{*}-\mathrm{C}^{*}<\mathrm{H}(\mathrm{H}) \text { [catalyzed by COS } \\
(\mathrm{H})>\mathrm{C}^{*}-\mathrm{O}^{*}+(\mathrm{H}) \mathrm{H}>\mathrm{C}^{*}-\mathrm{O}^{*}=>\mathrm{HO}-\mathrm{CH}(\mathrm{H})-\mathrm{C}^{*}(\mathrm{H})-\mathrm{O}^{*} \\
\mathrm{HO}-\mathrm{CH}(\mathrm{H})-\mathrm{C}^{*}(\mathrm{H})-\mathrm{O}^{*}+(\mathrm{H}) \mathrm{H}>\mathrm{C}^{*}-\mathrm{O}^{*}=\mathrm{HO}-\mathrm{CH}(\mathrm{H})-\mathrm{C}(\mathrm{OH}) \mathrm{H}-\mathrm{C}^{*}(\mathrm{H})-\mathrm{O}^{*} \\
\mathrm{HO}-\mathrm{CH}(\mathrm{H})-\mathrm{C}(\mathrm{OH}) \mathrm{H}-\mathrm{C}^{*}(\mathrm{H})-\mathrm{O}^{*}+(\mathrm{H}) \mathrm{H}>\mathrm{C}^{*}-\mathrm{O}^{*}=>\mathrm{HO}-\mathrm{CH}(\mathrm{H})-\mathrm{C}(\mathrm{OH}) \mathrm{H}-\mathrm{C}(\mathrm{OH}) \mathrm{H}-\mathrm{C}^{*}(\mathrm{H})-\mathrm{O}^{*} \\
\mathrm{HO}-\mathrm{CH}(\mathrm{H})-\mathrm{C}(\mathrm{OH}) \mathrm{H}-\mathrm{C}(\mathrm{OH}) \mathrm{H}-\mathrm{C}^{*}(\mathrm{H})-\mathrm{O}^{*}+(\mathrm{H}) \mathrm{H}>\mathrm{C}^{*}-\mathrm{O}^{*}=>\mathrm{HO}-\mathrm{CH}(\mathrm{H})-\mathrm{C}(\mathrm{OH}) \mathrm{H}-\mathrm{C}(\mathrm{OH}) \mathrm{H}- \\
\mathrm{C}(\mathrm{OH}) \mathrm{H}-\mathrm{C}^{*}(\mathrm{H})-\mathrm{O}^{*}
\end{gathered}
$$

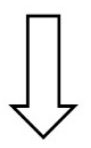

$$
\mathrm{HO}-\mathrm{CH}(\mathrm{H})-\mathrm{C}(\mathrm{OH}) \mathrm{H}-\mathrm{C}(\mathrm{OH}) \mathrm{H}-\mathrm{C}(\mathrm{OH}) \mathrm{H}-\mathrm{C}(\mathrm{H})=\mathrm{O}
$$

Scheme 1. Catalytic synthesis of ribose reaction steps 1-6.

(1) indicates, in relation to what is said above, that energy is transferred from the catalyst COS to the formaldehyde molecule. At the point of reaction, when enough vibrational quanta have been accepted by the $\mathrm{C}=\mathrm{O}$ bond of the $\mathrm{H} 2 \mathrm{CO}$ reactant, the double bond between $\mathrm{C}$ and $\mathrm{O}$ is weakened and self-supported, half-filled $2 \mathrm{p}$ orbitals (designated as ${ }^{*}$ ) are formed.

(2) illustrates the meeting of two equally excited molecules. The first happening is that one neutral hydrogen atom of the right-hand species is transferred to the (almost) half-filled $2 p$ orbital of the oxygen of the left-hand species. This results, pro primo, in the formation of an OH group (to the left) and, pro secundo, in the creation of a free valency at the carbon from which the H-atom has been 
snatched away. Thus, we get one C-atom with a half-filled $2 p$ orbital and another $C$-atom with an (almost) half-filled $2 p$ orbital. If the molecules concerned are positioned one above the other, this results in a 2p, $\mathrm{C}-\mathrm{C}$ bond, binding the two molecules together as indicated also in the left-hand formula of (c).

(3) $\mathrm{HO}-\mathrm{CH}(\mathrm{H})-\mathrm{C}^{*}(\mathrm{H})-\mathrm{O}^{*}+(\mathrm{H}) \mathrm{H}>\mathrm{C}^{*}-\mathrm{O}^{*}=>\mathrm{HO}-\mathrm{CH}(\mathrm{H})-\mathrm{C}(\mathrm{OH}) \mathrm{H}-\mathrm{C}^{*}(\mathrm{H})-\mathrm{O}^{*}$ indicates that the excitation of the right-hand part of the product from (2) has not lost its excitation. Thus, when meeting anew with a COS-excited $\mathrm{H} 2 \mathrm{CO}$ molecule the same procedure, as described above, can occur. This produces a molecule containing three carbon atoms as shown in (4).

In (4) and (5), two other excited formaldehydes, one in each row, are added in a similar way. This results in a molecule with five carbon atoms in which the $\pi$-orbital of the last added CO group is still split into $\mathrm{C}^{*}-\mathrm{O}^{*}$. This excitation, however, cannot last forever, and the five-carbon molecule relaxes to an aldehyde as shown in (6).

The linear molecule of Row $1 \mathrm{f}$ enters an equilibrium with a five-membered ring (Figure 3 ) and this process puts an end to further growth via carbon additions.

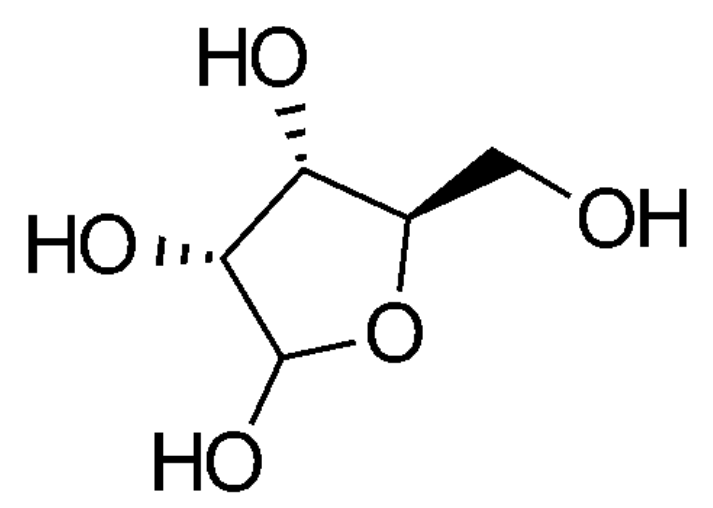

Figure 3. Ribose ( $\beta$-D-ribofuranose). Numbering code: first carbon on the left of the oxygen atom is $\mathrm{C} 1$. Last position in the five-ring is $\mathrm{C} 4$. The carbon in the side branch is $\mathrm{C} 5$.

\section{The SET Synthesis of Adenine from Hydrogen Cyanide (HCN)}

Although adenine can be synthesized under laboratory conditions from HCN, e.g., [11-13], it might be interesting to the possibilities for a SET synthesis under prebiotic conditions when HCN and COS came streaming out together from an undersea vent. One notes then that the molecular vibrations of HCN as given by Herzberg (table 42 and Figure 61 in reference [10]) are: $v 1=2089 \mathrm{~cm}^{-1}, v 2=$ $712 \mathrm{~cm}^{-1}$ and $v 3=3312 \mathrm{~cm}^{-1}$. We reproduce here in Figure 4 (the data from Figure 61 of Reference [10]).

As said above, the $v 3$ vibration of COS is $2079 \mathrm{~cm}^{-1}$ and that will give a good possibility of resonance between the two vibrations now described ( $v 3$ of COS and $v 1$ of $\mathrm{HCN}$ ).

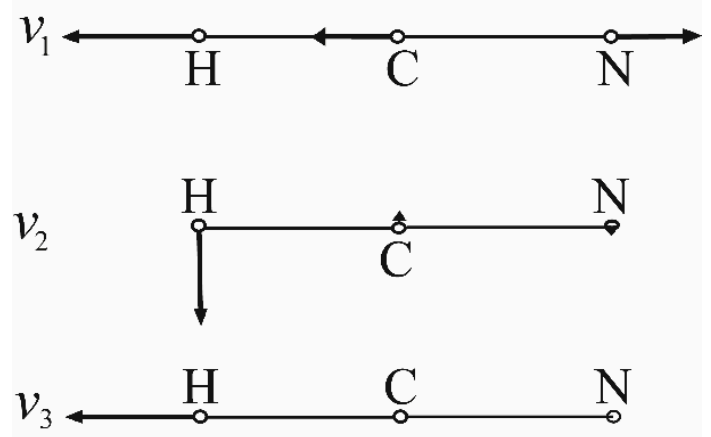

Figure 4. Vibrational pattern of hydrogen cyanide (HCN). Note that $v 1$ implies an increase of the C-N distance. 
Therefore, the more energy that is transferred from $\mathrm{COS}$ to $\mathrm{HCN}$, the larger will be the C-N distance in HCN. Because of this, the weaker will be the $2 \mathrm{p}-2 \mathrm{p}$ interaction in the HCN molecule; Scheme 2.

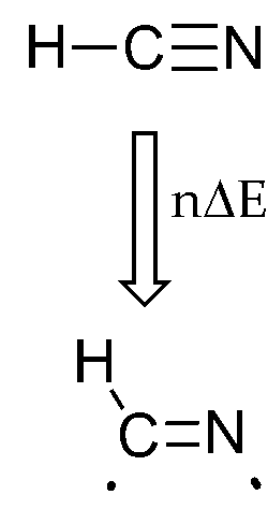

Scheme 2. Excitation of the HCN molecule.

In the Scheme 2. is shown excitation of the HCN molecule: $\Delta \mathrm{E}$ is the energy of one vibration quantum, given from the catalyst COS; $\mathrm{n}$ is the number of such quanta to reach reaction. Then the triple bond between $\mathrm{C}$ and $\mathrm{N}$ is destroyed and the resulting "free" $\mathrm{p}$ orbitals are designated by a point.

On the other hand, there will appear "freer" $2 p$ orbitals ready to join with a $2 p$ orbital of a neighboring molecule, whereby a single bond will be created between the two molecules. In Scheme 3 we illustrate this event with four of the five HCN molecules that are supposed to build the adenine molecule. The bond between $\mathrm{N}$ and $\mathrm{C}$ in the HCN molecule, activated by resonance with COS, is depicted as a double bond, what might possibly be an overstatement. Anyway, the appearance of a C-N single bond between two molecules makes it imperative that the two linear molecules attach in an angle approaching 120 degrees (weakly indicated in Scheme 3).

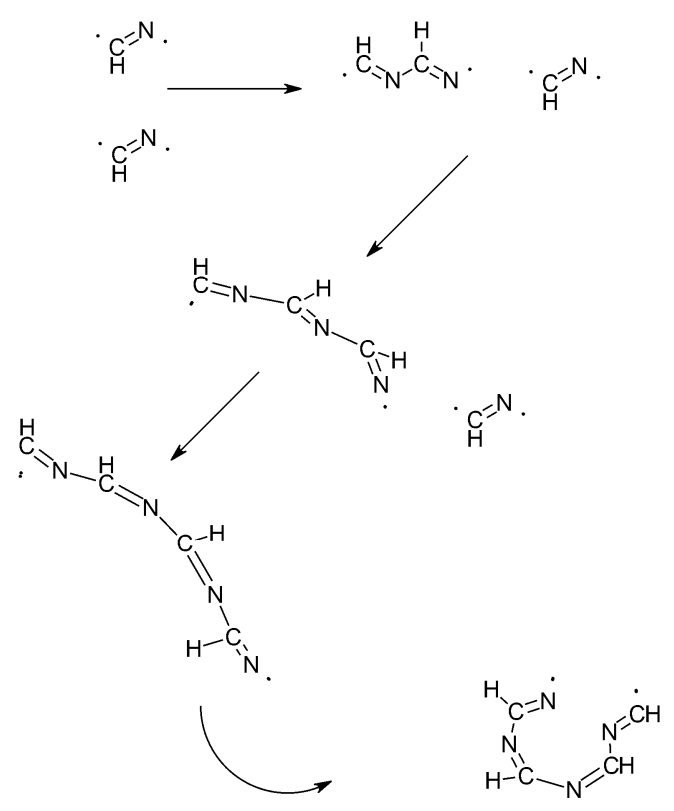

Scheme 3. An excited molecule is attacking another exited HC-N or an already formed polymer unit, $\mathrm{H}_{\mathrm{n}} \mathrm{C}_{\mathrm{n}} \mathrm{N}_{\mathrm{n}}$.

In Scheme 4 the gap that results between the first and the fourth HCN molecule is illustrated. This gap will be filled by the carbon atom from the fifth HCN molecule. It is difficult to tell in what form the $\mathrm{HCN}$ molecule molecule appears, but most probably it is the isomeric form $\mathrm{HNC}$, with two 
half-used p-orbitals available on the carbon atom (Scheme 4). The important point is that the carbon atom will find itself surrounded by three neighbouring atoms, more than willing to form new bonds with the intruder. This results, for one sake, in a weakening of the original $\mathrm{CN}$ triple bond so that the nitrogen atom is expelled and can bind to the carbon atom of the starting $\mathrm{HCN}$ unit. The two $\mathrm{H}$ atoms, that are set free in this maneuver, add to the $\mathrm{N}$ atom forming the top $\mathrm{NH}_{2}$ group.

Secondly, the result of the penetration of the last $\mathrm{HCN}$ molecule (or possibly $\mathrm{CN}^{-}$ion or $\mathrm{CNH}$ ) is, of course, that three new bonds are established what gives a closed structure; (Scheme 4 and Figure 5).

It is interesting to note that Jung and Choe [13] find, by CBS-QB3 calculations, that the formation in gas phase of oligomers $(\mathrm{HCN})_{n}$ where $n=2$ up to $n=5$ (adenine) requires very high activation energies. For each step of that reaction "a few hundred kJ" are used [13] and consequently a catalyst is strongly needed. These authors used a proton as a catalyst, that strongly decreased the activation energy. Nevertheless only "some oligomerization stages" were predicted [13] to occur in an atmosphere like that around the moon Titan (of the planet Saturn). No formation of adenine could, however, be foreseen. Near the surface of the planet Earth things might have been better. From hot volcano eruptions lots of hydrogen cyanide streamed out, but also lots of warm, already vibrationally excited carbonyl sulfide (COS). As this substance has shown good capacity as a catalyst [1], we allow ourselves to consider it as such also in this context.

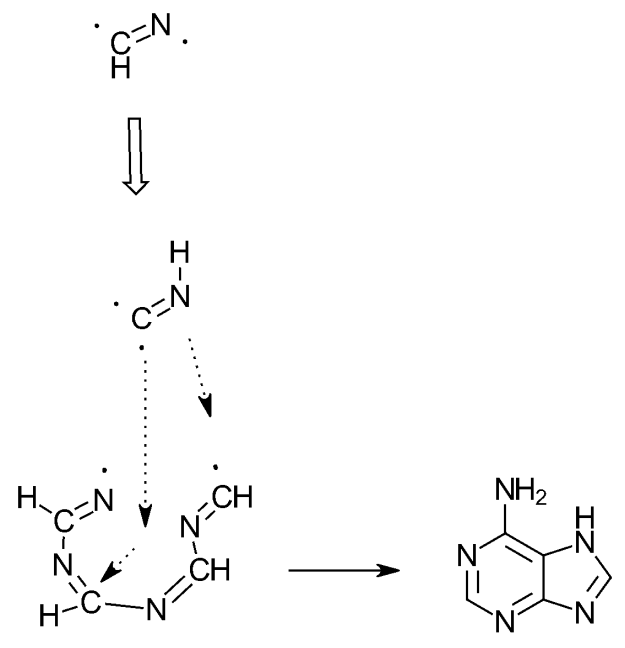

Scheme 4. A carbon atom from the fifth hydrogen cyanide $(\mathrm{HCN})$ unit in the grip of the already formed $\mathrm{H}_{4} \mathrm{C}_{4} \mathrm{~N}_{4}$ structure.

If it has entered this structure like a cork to a bottle or it is squeezed between the outer parts of that structure like a nail in the gap of a pair of tongs is difficult to tell. The creation of a C-C connection establishes the two ring structures coupled together as is also shown in Figure 5.

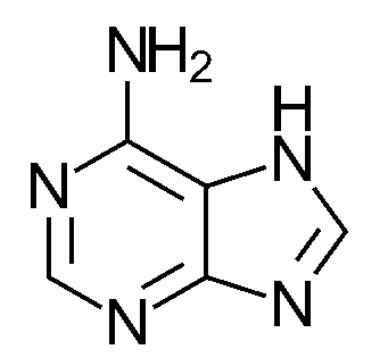

Figure 5. Structure of adenine. The numbering code is as follows: the $\mathrm{N}$ atom to the left of the $\mathrm{NH}_{2}$ carrying $\mathrm{C}$-atom is no 1 , and following, anti clockwise around the six-membered ring so that the above-mentioned $\mathrm{C}$-atom takes position no 6 . Thereafter, from positions 5 and 4 , around the five-membered ring one gets positions 7, 8, and 9. This means that the $\mathrm{N}-\mathrm{H}$ group is number 9. 


\subsection{Splitting One Oxygen Atom From $\mathrm{CO}_{2}$}

RNA is constituted from four different nitrogen bases, Figure 1. Besides Adenine, which is treated above, they are uracil $(\mathrm{U})$, guanine $(\mathrm{G})$, and cytosine $(\mathrm{C})$. All of the latter three molecules have one common trait that is lacking for adenine: they all contain oxygen. As the reactions discussed here were taking place under non-oxidative conditions, one might ask about the origin of that oxygen. Two possibilities can be considered: $\mathrm{CO}$ and $\mathrm{CO}_{2}$, both of volcanic origin. In this paper we concentrate on $\mathrm{CO}_{2}$.

Thus, given the existence of $\mathrm{CO}_{2}$ in the prebiotic atmosphere, how can it split off one separate oxygen atom, to take part in the construction of the nitrogen bases?

Nitrogen atoms appear, of course, also in the substances under study. Thus, one can assume that the atmosphere contained at least $\mathrm{CO}, \mathrm{CO}_{2}$ and ammonia. There were also other simple substances, e.g., $\mathrm{HCN}$ that could have acted to build the nitrogen bases.

\subsubsection{Carbon Dioxide Degradation}

Now, one can observe that there appears in the $\mathrm{CO}_{2}$ infrared spectrum a non-fundamental vibration composed by one $v 6$ (stretching) and one $v 10$ (bending of the three-atom line) [10]. This composite vibration appears at $2076.5 \mathrm{~cm}^{-1}$ and is designated as a medium strong IR absorber, (Table 56 in Reference [10]).

The frequency of this composite vibration is very close to that of the gaseous catalyst COS $\left(2079 \mathrm{~cm}^{-1}\right)$, with a very strong emission intensity. This equality of frequencies implies that a pronounced state of resonance could appear, resulting in an activation of the oxygen atoms. This atom can probably combine with the two hydrogens equally activated vibrating with e-symmetry in an ammonia molecule, resulting in the formation of water and a peptide group, discussion below.

\subsubsection{Ammonia Vibration Modes}

The catalyst for the reaction between $\mathrm{NH}_{3}$ and $\mathrm{CO}_{2}$ has been suggested to be gaseous $\mathrm{COS}$ as the critical vibrations are agreeing with the concept of SET. Among the vibrations of N-H stretch reported by Herzberg [10] we find one species at $4176 \mathrm{~cm}^{-1}$, meaning that it can obtain reaction energy from two quanta of COS $\left(2 \times 2079=4158 \mathrm{~cm}^{-1}\right)$. This composite vibration is assigned as $v 2$ (a) $+2 \vee 4$ (e), [10], i.e., the degenerate vibration appears twice that one with singular character. It seems to us that this composite vibration causes the expulsion of two hydrogen atoms, Figure 6, that reacts with the oxygen atom, activated as indicated above. One might say that both the $\mathrm{H}$ as well as the $\mathrm{O}$ atoms are in a statu nascendi, and hence have the capacity of reacting with each other.

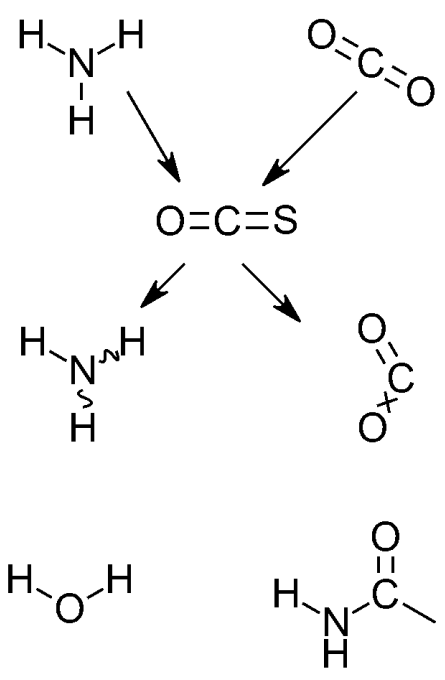

Figure 6. The catalyzed reaction between ammonia and carbon dioxide. 


\subsection{The Formation of the Oxygen-Containing Nucleobases Uracil, Guanine, and Cytosine from a SET Point of View}

Starting from the peptide group formed as described in Figure 6, (or, in one case, the two peptide groups) and the empirical formula for the molecule in question we try to understand the building of the nitrogen bases.

One notes that in all cases, Schemes 3 and 4 and Tables $2-4$, catalysis is a strongly working factor. In adenine, as described above, the entire structure is built up from five $\mathrm{HCN}$ molecules, where the vibration of the carbon-nitrogen bond is activated by the gaseous catalyst COS.

For the three remaining nitrogen bases, the structure is started by the formation of a peptide group created by the action of the same catalyst, $\mathrm{COS}$, on the splitting of $\mathrm{CO}_{2}$ molecule mixed with ammonia as described above, Figure 6. The results are collected in Tables 2-4.

As the peptide unit covers two positions in the ring system of guanine (Table 3), only four HCN molecules are needed to complete the structure. As in the case of adenine, the last HCN molecule (or rather the isomer form $\mathrm{CNH}$ ) is split into a carbon, entering a double bond, and the remaining $\mathrm{N}-\mathrm{H}$ unit that takes part in the formation of an amino group. In both cases (adenine and guanine) the amino group is positioned on the larger ring of the molecule. In addition, in both cases, the carbon atom is squeezed by the outer part of the structure.

The remaining two nitrogen bases form only one ring, but differs between themselves in that uracil contains two peptide groups. From the empirical formula of uracil it follows that an additional $\mathrm{C} 2 \mathrm{H} 2$ group is needed to complete the structure (Table 3). We suggest that this group originates from an ethene molecule. In addition, in this case catalysis is of decisive importance. One finds that (in Herzberg's Table 92; Reference [10]) there is tabulated a strong fundamental vibration, ${ }_{9}{ }^{\mathrm{CH}}\left(\mathrm{b}_{2 \mathrm{u}}\right)$, at $3105.5 \mathrm{~cm}^{-1}$. The (inverted) resonance condition is therefore $3105.5 / 2079=1.4937$; this means that the difference from 1.5000 is 0.0063 or 4.2 permillage. This is a very reasonable value for resonance.

This means that two quanta of $v_{9}$ accepts energy from three quanta of the catalyst. Now it turns out [10], that $v_{9}$ has a form as shown in Figure 7, that implies that at high excitation of their vibration, the two "upper" $\mathrm{H}$-atoms are distancing themselves (and together) from the compact rest of the molecule, i.e., $\mathrm{C}_{2} \mathrm{H}_{2}$. This results, after bond breaking at a suitable excitation level, in a $\mathrm{H}_{2}$ molecule and a remaining rest of $\mathrm{H}-\mathrm{C}^{*}=\mathrm{C}^{*}-\mathrm{H}$, with two free valencies, that can form bonds with other -excitedatoms (Tables 2 and 4 ).

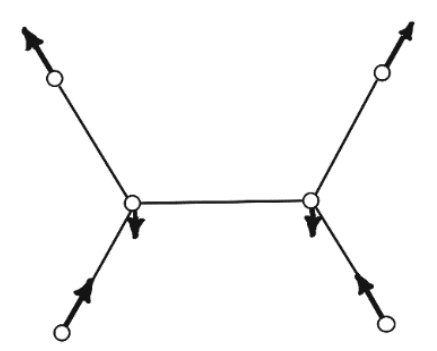

Figure 7. The $v 9$ vibration pattern of an $\mathrm{X}_{2} \mathrm{Y}_{4}$ planar molecule-let it be $\mathrm{C}_{2} \mathrm{H}_{4}$ with the hydrogen atoms in periphery — from part of a scheme by Herzberg (figure 57 in [10] here $\vee 9$ is one out of twelwe symmetry coordinates.).

Cytosine has the most complex structure of the four substances discussed here. We suggest (Table 4), that $\mathrm{HCN}, \mathrm{NH}_{3}$ and $\mathrm{C}_{2} \mathrm{H}_{4}$ are involved, in a 1:1:1 ratio and that all three substances are activated by the catalyst $\mathrm{COS}$ as described above.

Most reasonably ammonia, $\mathrm{NH}_{3}$, will decompose into $=\mathrm{NH}$ and $\mathrm{H}_{2}$ (compare Figure 6) and $\mathrm{C}_{2} \mathrm{H}_{4}$ will decompose into $\mathrm{C}_{2} \mathrm{H}_{2}$ and $\mathrm{H}_{2}$ (compare Tables 2 and 4).

Figure 8 shows the structure of uracil, and in Table 2 is shown its gradual growth. 




Figure 8. The structure of uracil.

Table 2. The gradual growth of uracil.

\begin{tabular}{|c|c|c|c|}
\hline Uracil & \multicolumn{2}{|c|}{ Empirical Formula } & $\mathrm{C}_{4} \mathrm{H}_{4} \mathrm{~N}_{2} \mathrm{O}_{2}$ \\
\hline Substance added & Resulting Structure & $\begin{array}{l}\text { Resulting empirical } \\
\text { formula }\end{array}$ & Remaining formula \\
\hline Two peptide groups & & $\mathrm{C}_{2} \mathrm{H}_{2} \mathrm{~N}_{2} \mathrm{O}_{2}$ & $\mathrm{C}_{2} \mathrm{H}_{2}$ \\
\hline $\mathrm{H}$ & & $\mathrm{C}_{4} \mathrm{H}_{4} \mathrm{~N}_{2} \mathrm{O}_{2}$ & $\mathrm{H}_{2}$ \\
\hline
\end{tabular}

Figure 9 shows the structure of guanine, in Table 3 is shown its gradual growth.

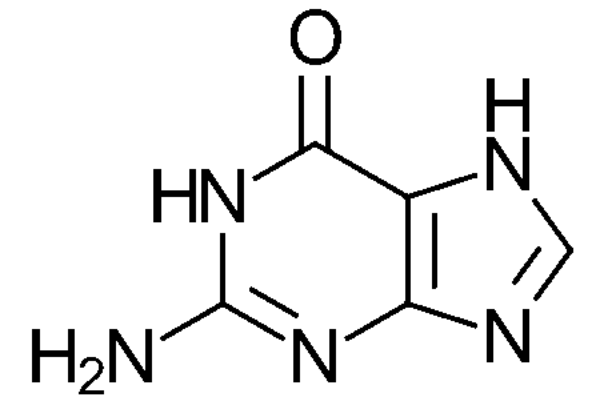

Figure 9. Structure of Guanine. 
Table 3. The gradual growth of guanine.

\begin{tabular}{cccc}
\hline Guanine & \multicolumn{2}{c}{ Empirical Formula } & $\mathrm{C}_{5} \mathrm{H}_{5} \mathrm{~N}_{5} \mathrm{O}$ \\
\hline Added substance & Resulting empirical & Remaining formula \\
One peptide group & & & \\
\hline $3 \mathrm{HCN}$ & & & \\
\hline & & & \\
\hline
\end{tabular}

Nothing added or remaining.

Figure 10 shows the structure of cytosine, and in Table 4 is shown its gradual growth.

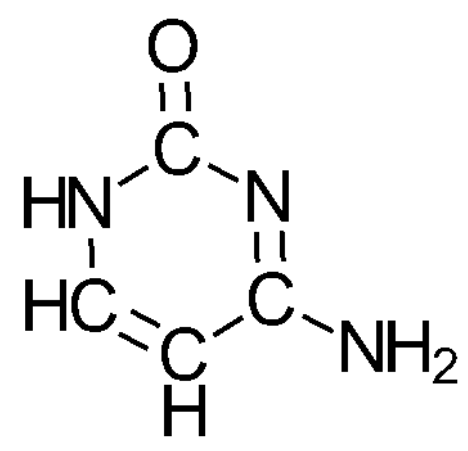

Figure 10. Structure of cytosine. 
Table 4. The gradual growth of cytosine.

\begin{tabular}{|c|c|c|c|}
\hline Cytosine & Empiric & & $\mathrm{C}_{4} \mathrm{H}_{5} \mathrm{~N}_{3} \mathrm{O}$ \\
\hline Added substance & Resulting Structure & $\begin{array}{l}\text { Resulting empirical } \\
\text { formula }\end{array}$ & Remaining formula \\
\hline One peptide group & & $\mathrm{CHNO}$ & $\mathrm{C}_{3} \mathrm{H}_{4} \mathrm{~N}_{2}$ \\
\hline $\mathrm{HCN}$ & & $\mathrm{C}_{2} \mathrm{H}_{2} \mathrm{~N}_{2} \mathrm{O}$ & $\mathrm{C}_{2} \mathrm{H}_{3} \mathrm{~N}$ \\
\hline $\mathrm{NH}_{3}=\mathrm{NH}+\mathrm{H}_{2}$ & & $\mathrm{C}_{2} \mathrm{H}_{3} \mathrm{~N}_{3} \mathrm{O}$ & $\mathrm{C}_{2} \mathrm{H}_{2}+\mathrm{H}_{2}$ \\
\hline $\begin{array}{l}\mathrm{H}_{2} \mathrm{C}^{=\mathrm{CH}_{2}}= \\
{\stackrel{\mathrm{H}}{\mathrm{H}}=\stackrel{\mathrm{H}}{=}+\mathrm{H}^{-\mathrm{H}}}^{\mathrm{H}}+\end{array}$ & $\begin{array}{l}\mathrm{HN} \\
\mathrm{H} \\
\mathrm{HC}\end{array}$ & $\mathrm{C}_{4} \mathrm{H}_{5} \mathrm{~N}_{3} \mathrm{O}$ & $2 \mathrm{H}_{2}$ \\
\hline
\end{tabular}

\section{Additions to the Ribose Structure}

As seen from Figure 1, ribose is the carrying tool for different molecules, nucleobases, where the combining part of the ribose molecules are phosphate groups.

These chains, presenting a collection of biophysical properties are, as is well known, of great biological importance. Therefore, it is of essential importance to know how the mechanics of keeping such a chain together works.

In addition, here, we find that carbonyl sulfide catalysis works to establish good bonding conditions, whether it is the ribose-phosphate bonding, or it is the ribose nucleobase combination that is concerned.

In the following, we will discuss testing methods that might indicate how this chain formation takes place.

\subsection{Phosphorylation of Carbohydrates, e.g., Glucose and Ribose}

To evaluate the phosphorylation of carbohydrates, e.g., glucose or ribose, in the presence of COS, we have collected some relevant IR-data. We have concentrated here on the $v 3$ vibration of COS, testing if ring vibrations of ribose are as stimulated by the catalyst as the vibrations (e.g., $\rho_{\mathrm{W}}\left(\mathrm{NH}_{2}\right)$ ) described in the previous investigation [1].

This activity might to a part depend on the strong IR absorption, and consequently very strong IR emission band of COS at $2079 \mathrm{~cm}^{-1}$ [9] and on the relatively intense P-O stretching vibrations of the phosphate groups at about $1045 \mathrm{~cm}^{-1}$. As cited in Reference [4], these data will give a 2:1 ratio for the 
COS/ $/ \mathrm{PO}_{4}$ vibrational quanta, 2079/1045 $=1.9895$ which is as close to resonance as one can demand. Here $1045 \mathrm{~cm}^{-1}$ is the mean of $1044 \mathrm{~cm}^{-1}$ [14] and $1046 \mathrm{~cm}^{-1}$ [15], compare Table 5 .

Table 5. IR data $\left(\mathrm{cm}^{-1}\right)$ for glucose $\mathrm{C}(6) \mathrm{O}-\mathrm{H}$ and solid-state phosphates [4]. The quoted assignments are from respective authors.

\begin{tabular}{cccc}
\hline Assignment & Glucose & Phosphate & References \\
\hline $\mathrm{PO}_{4}{ }^{3-} / \mathrm{HPO}_{4}{ }^{2-}$ asymmetric stretching & - & 1044 & {$[14]$} \\
\hline $\mathrm{PO}_{4}{ }^{3-}$ asymmetric stretching. & - & 1046 & {$[15]$} \\
\hline $\mathrm{C}-\mathrm{O}-\mathrm{H}$ & 1047 & - & {$[16]$} \\
\hline$v \mathrm{CO}+v \mathrm{CC}$ & 1050 & - & {$[17]$} \\
\hline $\mathrm{CO}(79 \%)+\mathrm{CC}(19 \%)$ PED & 1047 & - & {$[18]$} \\
\hline Mean value & 1048 & 1045 & - \\
\hline
\end{tabular}

PED $=$ Percentage Electron Density.

\subsubsection{Glucose}

The above-mentioned observation is of great interest as the vibrationally excited $\mathrm{PO}_{4}{ }^{3-}$ is a key substance for the phosphorylation of, e.g., glucose [4]. One notes that the reaction, just mentioned, also involves an activation-via the COS vibration-of the $\mathrm{C}(6)-\mathrm{OH}$ vibration of glucose at about $1048 \mathrm{~cm}^{-1}$, [4], with an equally good resonance state as obtained for the above-mentioned activation of the $\mathrm{PO}_{4}$ group. The relevant vibrational data [4] are presented once more here in Table 5, where [16-18] refer to data for glucose and $[14,15]$ refer to data for phosphate.

Thus, e.g., an activated $\mathrm{PO}_{4} \mathrm{H}^{2-}$ might approach an equally activated $\mathrm{C}(6)-\mathrm{OH}$ group, resulting in the formation of a $\mathrm{H}_{2} \mathrm{O}$ molecule and the binding of a phosphate group to the sugar molecule.

\subsubsection{Ribose}

If the above reasonings hold also for a pentose substance they will indicate the starting point for the formation of the ATP molecule (adenosine triphosphate). Actually, one finds (Table 6, References [19-21]) a corresponding C(5)-OH vibration of ribose, with a mean value, ca $1040 \mathrm{~cm}^{-1}$ that fits rather well for an interaction with the phosphate system $\left(1045 \mathrm{~cm}^{-1}\right)$ shown in Table 6.

Table 6. Vibrational data for phosphates and ribose.

\begin{tabular}{ccccccc}
\hline Row & Assignment & Ribose & Phosphate & R.C. & $\boldsymbol{\Delta} \%$ & Reference \\
\hline 1 & $\mathrm{PO}_{4}{ }^{3-} / \mathrm{HPO}_{4}{ }^{2-}$ asymmetric stretching & - & 1044 & 1.991 & 4.5 & {$[14]$} \\
\hline 2 & $\mathrm{PO}_{4}{ }^{3-}$ asymmetric stretching & - & 1046 & 1.988 & 6.0 & {$[15]$} \\
\hline 3 & $v \mathrm{C}-\mathrm{O}+v(\mathrm{C}-\mathrm{C})$, etc. & $1044^{*}$ & - & 1.982 & 9.0 & {$[19]$} \\
\hline 4 & $\delta(\mathrm{O}-\mathrm{C}-\mathrm{H})$ & 1035 & - & 2.009 & 4.5 & {$[20]$} \\
\hline 5 & Not assigned & 1041 & - & 1.997 & 1.5 & {$[21]$} \\
\hline & Mean value & 1040 & 1045 & - & - & - \\
\hline
\end{tabular}

All data in $\mathrm{cm}^{-1}$. All assignments relate to the respective authors. R.C. $=$ "resonance condition" means the ratio between the COS catalyst frequency $\left(2079 \mathrm{~cm}^{1}\right)$ and the tabulated frequency. $\Delta=$ difference (in per-millage) to nearest even digits. Mean value of $\Delta \%=5$ per-millage. ${ }^{*}$ Mean value of $v C O+v C C\left(1078 \mathrm{~cm}^{-1}\right)$ and $v C(1) \mathrm{O}$ $+v C(1) C\left(1010 \mathrm{~cm}^{-1}\right)=1044 \mathrm{~cm}^{-1}$. [Reference 20; Table 2 of that reference]. Because of structural information, we have omitted data related to $C(2)$.

\subsection{The Attachment of Adenine to Ribose}

Adenine (Figure 5) is one of the important building blocks of ATP or adenosine triphosphate. We use here ATP as a small-scale example of adenine bonding. If we accept that the $\mathrm{C}(5)$ position of the ribose is the one first occupied by the $\mathrm{PO}_{4}$ group it is tempting to assign the opposite position 
of the ribose molecule, $\mathrm{C}(1)$, for anchoring the adenine molecule. This view is supported by well known structure data, Figure 11. We will use ATP as a model example for describing the bonding of nucleobases, all with an $\mathrm{N}-\mathrm{H}$ group, towards the $\mathrm{C}(1)$ position of ribose.

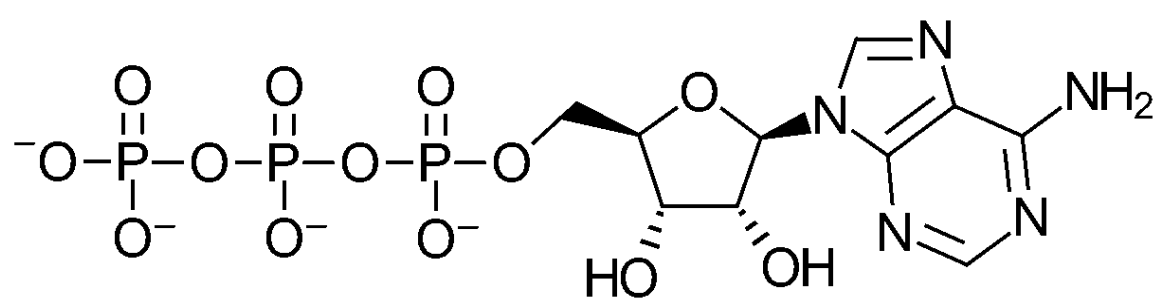

Figure 11. Adenosine triphosphate (ATP) is a combination of one adenine, one ribose and three phosphate groups.

As the picture of ATP shows (Figure 11), the connection between the adenine N(9)-H and the ribose $\mathrm{C}(1)-\mathrm{OH}$ keeps the different groups together. How does this extremely important bond come about? It is known that the C-O + C-C vibration is found at about $1040 \mathrm{~cm}^{-1}$ (table 6, in [19-21]).

But what is known about vibrations of the $\mathrm{N}(9)-\mathrm{H}$ group that might be in close resonance with the vibrations of the $\mathrm{C}(1)-\mathrm{OH}$ moiety? To follow the treatment discussed above we plot a series of FTIR data [22] as shown in Table 7.

Table 7. Series of FTIR data on anhydrous adenine, numbers $1-5$, from an investigation with detailed analysis of the spectral assignments. The "resonance condition" is calculated as was done in Table 1.

\begin{tabular}{cccccc}
\hline Number & Assignment * & $\begin{array}{c}\text { IR Vibration } \\
\text { Frequency, } \\
\text { cm }^{-1}\end{array}$ & $\begin{array}{c}\text { Resonance } \\
\text { Condition } \\
\text { (R. C.) }\end{array}$ & $\begin{array}{c}\text { Ideal } \\
\text { Value }\end{array}$ & $\begin{array}{c}\text { Deviation } \boldsymbol{\Delta} \\
\text { (o/oo) }\end{array}$ \\
\hline 1 & $v(\mathrm{~N} 9-\mathrm{H})$ & 3016 & 0.689 & - & - \\
\hline 2 & $\delta(\mathrm{N} 9-\mathrm{H})+7$ extra terms & 1603 & 1.297 & 1.333 & 27 \\
\hline 3 & $\delta(\mathrm{N} 9-\mathrm{H})+10$ extra terms & 1508 & 1.379 & 1.333 & 35 \\
\hline 4 & $\delta(\mathrm{N} 9-\mathrm{H})+8$ extra terms & 1450 & 1.434 & 1.500 & 44 \\
\hline 5 & $\delta(\mathrm{N} 9-\mathrm{H})+9$ extra terms & 1367 & 1.521 & 1.500 & 14 \\
\hline
\end{tabular}

* The "extra terms" in column 2 (mostly stretching vibration but also some bending ones) are given [23], but with no quantitative estimations.

Table 7 shows a series of FTIR data on anhydrous adenine.

From the data given in Table 7, we can safely assume that Row 5 represents a condition where the 'extra terms' give the least disturbance when calculating the vibration frequency of $\delta(\mathrm{N} 9-\mathrm{H})$. We, therefore, set forth to find a correction that will give us a 'true' value of this parameter, and thereby understand the transfer of energy from catalyst to the intended reactant.

As above (Table 7; Row 5) we can state that (1.521-1.500)/1.5 = $14 \mathrm{o} / \mathrm{oo}$.

Hence, to reach an expected, somewhat smaller, value of the resonance condition, one has to increase the denominator with a term that we call $\Delta^{\prime \prime}$.

$\Delta^{\prime \prime}=0.014 \times 1367 \mathrm{~cm}^{-1}=19 \mathrm{~cm}^{-1}$.

Thus, the true value of $\delta(\mathrm{N} 9-\mathrm{H})=1367+19=1386 \mathrm{~cm}^{-1}$.

We can now check the calculations by forming the expression for resonance condition, R.C. = $2079 / 1386=1.500=3: 2$. This gives full support to our treatment.

If we express the value of a vibrational quantum in $\mathrm{cm}^{-1}$ units, this means that two catalyst quanta $=2 \times 2079 \mathrm{~cm}^{-1}=4158 \mathrm{~cm}^{-1}$, and three reactant quanta $=3 \times 1386 \mathrm{~cm}^{-1}=4158 \mathrm{~cm}^{-1}$.

Thus, two vibrational quanta from the catalyst are donated and three quanta are accepted by the reactant for the reaction to go. 
Furthermore, one can now check if the conditions for resonance-and consequently energy exchange-between the adenine molecule and ribose is at hand. Using the mean value of the $\mathrm{C}-\mathrm{OH}$ vibration of ribose as $1040 \mathrm{~cm}^{-1}$ (Table 6), we can detect that the ratio between adenine and ribose vibrational quanta is $1386 \mathrm{~cm}^{-1} / 1040 \mathrm{~cm}^{-1}=1.3327$, i.e., $4: 3$.

This means, that for the reaction of binding adenine to ribose to occur, the energy of excitation of the reaction partners should be equal: $3 \times 1386 \mathrm{~cm}^{-1}=4158 \mathrm{~cm}^{-1}$, and $4 \times 1040 \mathrm{~cm}^{-1}=4160 \mathrm{~cm}^{-1}$.

This result suggests that this type of bonding should hold also for the other three nucleobases. Thus, the deductions made above strengthen our reasoning in the introduction. It is also of interest to note that $\delta(\mathrm{N} 9-\mathrm{H})=1386 \mathrm{~cm}^{-1}$ is in good correspondence to the same data $\left(1382 \mathrm{~cm}^{-1}\right)$, measured by the Inelastic Neutron Scattering (INS) method [22].

\subsection{Total Synthesis}

When all four nucleobases are present, they can form RNA by combining with ribose molecules which, in their turn, are kept together by $\mathrm{PO}_{4}{ }^{3-}$ units as described in detail for adenine in Sections 3.1 and 3.2. A fraction of the result is shown in Figure 1. It must be emphasized that the coupling between the remaining three nucleobases and ribose is like that described for adenine and ribose (Section 4.2):

Uracil, with two N-H groups (Figure 8) uses that group that gives the largest steric availability. Figure 1 shows that the choice of bonding site fulfills the requirements.

For guanine, with a structure like adenine, it is the N9-H group (compare Figures 1 and 9) that reacts with the $\mathrm{C} 1-\mathrm{OH}$ group.

Cytosine with only one N-H group reacts with that one, cf. Figures 1 and 10.

One may note that in many, not to say most, of the reactions described here, there occurs the formation and removal of one molecule of $\mathrm{H}_{2} \mathrm{O}$, i.e., a "condensation". The fact that $\mathrm{COS}$ is the catalyst in all these reactions is remarkable (see below).

\section{Conclusions}

We have found that it seems possible to build (or suggest a scheme for building) all the nucleobases that make up the RNA chain from a few simple molecules, such as $\mathrm{HCN}, \mathrm{CO}_{2}, \mathrm{NH}_{3}, \mathrm{C}_{2} \mathrm{H}_{4}$, providing that a certain order between the reactants is kept up, and that one uses the concept of SET (selective energy transfer) for catalysis of the reaction steps involved.

We have also found that for all reactions considered there is a ratio in small numbers; 1:2, 1:1, 3:2, $4: 3$, etc. between the vibration quanta of catalyst and reactant, well in accordance with the rules of the SET model.

What is extraordinary and definitely interesting from the view-point of "the origin of life", is that in all cases the catalyst is one and the same substance, the carbonyl sulfide, COS; or rather SCO to emphasize its relation to carbon dioxide (Table 8). One finds reason to use COS as a catalyst not only for the synthesis of the ribose and the four nucleobases, not only for the splitting of carbon dioxide and the splitting of ammonia and ethene, but also for the conversion of amino acids to chains of peptide groups as described in Reference [1]. Further, this gas, COS, came from the-at the time-not so uncommon volcanic eruptions! We are tempted to cite the expression [23], coined by the Nobel Laureate Christian de Duve: COS must be "the dust of life". (This, of course, is our later-days interpretation). 
Table 8. The influence of the catalyst COS $\left(\omega=2079 \mathrm{~cm}^{-1}\right)$ on the reactions mentioned here, indicating the type of interaction.

\begin{tabular}{|c|c|c|c|c|c|c|}
\hline Reactant & $\begin{array}{c}\text { Critical } \\
\text { Vibration } \\
\mathrm{cm}^{-1}\end{array}$ & $\begin{array}{c}\text { Route of } \\
\text { Attack }\end{array}$ & $\omega / v$ & $\begin{array}{l}\text { Deviation } \\
\text { o/oo }\end{array}$ & Product & Reference \\
\hline $\mathrm{H}_{2} \mathrm{CO}$ & $v_{2}=1743.6$ & $\begin{array}{l}\text { Double bond } \\
\text { splitting }\end{array}$ & $6: 5$ & 6 & $\begin{array}{c}\text { Ribose } \\
\mathrm{C}_{5} \mathrm{H}_{5} \mathrm{O}_{5}\end{array}$ & $\begin{array}{c}{[10]} \\
\text { Table } 2 \\
\end{array}$ \\
\hline $\mathrm{HCN}$ & $v_{1}=2089$ & $\begin{array}{c}\text { Triple bond } \\
\text { splitting }\end{array}$ & $1: 1$ & 5 & Adenine & $\begin{array}{l}\text { Schemes } 3 \\
\text { and } 4\end{array}$ \\
\hline $\mathrm{CO}_{2}$ & $v 6+v 10=2076.5$ & $\begin{array}{l}\text { Vibration } \\
\text { energy } \\
\text { transfer }\end{array}$ & $1: 1$ & 1 & $\mathrm{CO}+\mathrm{O}$ & $\begin{array}{c}{[10]} \\
\text { Figure } 6\end{array}$ \\
\hline $\mathrm{NH}_{3}$ & $v 2(a)+2 \vee 4(e)=4176$ & $\begin{array}{l}\text { Vibration } \\
\text { energy } \\
\text { transfer }\end{array}$ & $1: 2$ & 4 & $\mathrm{NH}+\mathrm{H}_{2}$ & $\begin{array}{c}{[10]} \\
\text { Figure } 6\end{array}$ \\
\hline $\mathrm{C} 2 \mathrm{H} 4$ & $v_{9}{ }^{\mathrm{CH}}\left(\mathrm{b}_{2 \mathrm{u}}\right)=3105.5$ & $\begin{array}{l}\text { Double bond } \\
\text { splitting }\end{array}$ & $2: 3$ & 4 & $\mathrm{C}_{2} \mathrm{H}_{2}+\mathrm{H}_{2}$ & $\begin{array}{l}\text { Table } 2 \\
\text { (in [10]) }\end{array}$ \\
\hline $\begin{array}{l}\mathrm{PO}_{4}{ }^{3-} \\
\text { glucose }\end{array}$ & $\begin{array}{l}1045 \\
1048\end{array}$ & $\begin{array}{l}\text { Molecular } \\
\text { Interaction }\end{array}$ & $\begin{array}{l}2: 1 \\
2: 1\end{array}$ & $\begin{array}{c}1048 / 1045=1.0048 \\
5 \text { o/oo }\end{array}$ & Phospho-glucose- & $\begin{array}{c}{[4]} \\
\text { Table } 5\end{array}$ \\
\hline $\begin{array}{l}\mathrm{PO}_{4}{ }^{3-} \\
\text { ribose }\end{array}$ & $\begin{array}{l}1045 \\
1040\end{array}$ & $\begin{array}{l}\text { Molecular } \\
\text { interaction }\end{array}$ & $\begin{array}{c}2: 1 \\
2=1\end{array}$ & $\begin{array}{c}1045 / 1040=1.0048 \\
5 \mathrm{o} / \mathrm{oo}\end{array}$ & Phospho-ribose & $\begin{array}{l}{[19,20]} \\
\text { Table } 6\end{array}$ \\
\hline $\begin{array}{l}\text { Ribose } \\
\text { adenine }\end{array}$ & $\begin{array}{l}1040 \\
1386\end{array}$ & $\begin{array}{l}\text { Molecular } \\
\text { interaction }\end{array}$ & $\begin{array}{c}2: 1 \\
3: 2 \\
2 / 1.5=4: 3 \\
\end{array}$ & $\begin{array}{c}1386 / 1040=1.327 \\
5 \text { o/oo }\end{array}$ & Adenine-ribose & $\begin{array}{c}{[22]} \\
\text { Table } 7\end{array}$ \\
\hline $\begin{array}{l}\text { Amino- } \\
\text { acetate } \\
\left(\mathrm{Cu}^{2+}\right) \\
\mathrm{COS}\end{array}$ & $\begin{array}{l}1058 \\
2079\end{array}$ & $\begin{array}{l}\text { Molecular } \\
\text { interaction }\end{array}$ & $\begin{array}{l}1: 2 \\
1: 1\end{array}$ & $\begin{array}{c}2 \times 1058=2116 \\
2116 / 2079=1.0178 \\
9 \text { o/oo }\end{array}$ & $\begin{array}{c}\text {-NH-CO- } \\
\text { (Condensation of } \\
\text { amino acids) }\end{array}$ & [1] \\
\hline
\end{tabular}

But that phrase, "the dust of life", also stresses the weak point of our results; a gaseous substance would have difficulties to stay inside the walls of a living cell. It is now well known, however, that small, solid particles of montmorillonite (a type of petrified clay) might be trapped in such protocells in which RNA might operate [24,25]. Especially interesting for us is the concept "everything first", coined in this context by Sutherland [26,27], indicating that if all the reactions, needed to build the cell and its contents, were served by one and the same catalyst, the various components must be formed simultaneously, side by side irrespective of the catalyst being a gas or a petrified clay. Sutherland's concept also implied that no special part of the total cell was assigned to lead the run, having to see the others slowly following up.

Therefore, hopefully, we will be able to discuss similarities and differences between gas systems and solid-state catalysts in the next part of this breath-taking tale on the power of SET.

Author Contributions: The activities for producing the manuscript relate as follows: conceptualization, R.L. and A.M.; literature search and evaluation, A.M.; calculations, R.L.; methodology, R.L. and I.O.; writing-original draft, A.M. and R.L.; data collection and evaluation, A.M. and R.L.; drawings and manuscript corrections, I.O. All authors have read and agreed to the published version of the manuscript.

Funding: This research received no external funding.

Acknowledgments: The authors are grateful for the support for this work provided by the University of Lund and the Department of Chemical Engineering of LU. This support was aimed at covering the costs of publishing the results of the study in full Open Access style. One of us (R. L.) will strongly thank his daughter, Karin Lilja, B.Sc., for good guidance in computer use. Likewise, we, the authors, want to express our gratitude to Mr. Farhan Zaman of Ottawa, Canada, for his computer related help. We are also indebted to Mr. Lars Fembro for his help with the figures of vibration patterns.

Conflicts of Interest: The authors declare no conflict of interest. 


\section{References}

1. Larsson, R.; Malek, A. The transformation by catalysis of prebiotic systems to useful biochemicals: A perspective based on IR spectroscopy of the primary chemicals. I. The Synthesis of Peptides by the Condensation of Amino Acids. Appl. Sci. 2019, 10, 928. [CrossRef]

2. Larsson, R. A Model of Selective Energy Transfer at the Active Site of the Catalyst. J. Mol. Catal. 1989, 55, 70-83. [CrossRef]

3. Larsson, R. Concluding remarks on the theory of selective energy transfer and exemplification on a zeolite kinetics study. Monatsh. Chem. 2013, 144, 21-28. [CrossRef]

4. Larsson, R. A SET Approach to the Interplay of Catalysts and Reactants. Catalysts 2018, 8, 97. [CrossRef]

5. Kittel, C.; Knight, W.D.; Ruderman, M.A. Mechanics; Berkeley Physics Course; McGraw-Hill: New York, NY, USA, 1966; Volume 1, Chapter 7.

6. Larsson, R. On the Stepwise Change of the Activation Energy of Catalytic Reactions. Z. Phys. Chemie, Leipzig 1987, 268, 721-732. [CrossRef]

7. NIST Chemistry Webbook. Available online: http://webbook.nist.gov/chemistry (accessed on 14 November 2014).

8. Herzberg, G. Spectra of Diatomic Molecules, 1st ed.; Van Nostrand Co., Inc.: New York, NY, USA, 1950.

9. Keane, M.A.; Larsson, R. Isokinetic behavior in gas phase catalytic hydrodechlorination of chlorobenzene over supported nickel. J. Mol. Catal. 2007, 268, 87-94. [CrossRef]

10. Herzberg, G. Molecular Spectra and Molecular Structure, II. Infrared and Raman Spectra of Polyatomic Molecules; D van Nostrand Company, Inc.: Princeton, NJ, USA, 1962.

11. Oró, J. Mechanism of Synthesis of Adenine from Hydrogen Cyanide under Possible Primitive Earth Conditions. Nature 1961, 191, 1193-1194. [CrossRef]

12. Voet, A.B.; Schwartz, A.W. Prebiotic adenine synthesis from HCN. Evidence for a newly discovered major pathway. Bioorg. Chem. 1983, 12, 8-17. [CrossRef]

13. Jung, S.H.; Choe, J.C. Mechanisms of prebiotic adenine synthesis from HCN by oligomerization in the gas phase. Astrobiology 2013, 13, 465-475. [CrossRef]

14. Frost, R.L.; Xi, Y.; Scholtz, R.; Lopez, A.; Belatti, F.M. Vibrational spectroscopic characterization of the phosphate mineral hureaulite-(Mn,Fe $)_{5}\left(\mathrm{PO}_{4}\right)_{2}\left(\mathrm{HPO}_{4}\right)_{2}{ }^{*} 4\left(\mathrm{H}_{2} \mathrm{O}\right)$. Vib. Spectrosc. 2013, 66, 69-75. [CrossRef]

15. Mejoo, S.; Maneeprakorn, W.; Winotai, P. Phase and thermal stability of nanocrystalline hydroxyapatite prepared via microwave heating. Thermochim. Acta 2006, 447, 115-120. [CrossRef]

16. Kovacs, A.; Ivanov, A.Y. Vibrational Analysis of D-Glucose Trapped in Ar-Matrix. J. Phys. Chem. B 2009, 113, 2151-2159. [CrossRef] [PubMed]

17. Ibrahim, M.; Alaam, M.; El-Haes, H.; Jalbout, A.F.; de Leon, A. Analysis of the structure and vibrational spectra of glucose and fructose. Ecletica Quimica 2006, 31, 15-21. [CrossRef]

18. Vasko, P.D.; Blackwell, J.; Koenig, J.L. Infrared and Raman Spectroscopy of Carbohydrates. Part II: Normal Coordinate Analysis of D-Glucose. Carbohydr. Res. 1972, 23, 407-416. [CrossRef]

19. Carmona, P.; Molina, M. Raman and infrared spectra of D-ribose and D-ribose 5- phosphate. J. Raman Spectrosc. 1990, 21, 395-400. [CrossRef]

20. Mathlouthi, M.; Seuvre, A.M.; Koenig, J.L.F.T.-I.R. Laser-Raman spectra of D-Ribose and 2-Deoxy-D-erythro-Pentose (2-Deoxy-D-Ribose). Carbohydr. Res. 1983, 122, 31-47. [CrossRef]

21. Tipson, R.S.; Isbell, H.S. Infrared Absorption Spectra in the Study of Mutarotational Equilibria of Monosacharides. J. Res. NBS—A Phys. Chem. 1962, 66A, 31-58. [CrossRef]

22. Lopes, R.P.; Valero, R.; Tomkinson, J.; Marques, M.P.M.; de Carvalino, L.A.E.B. Applying vibrational spectroscopy to the study of nucleobases-Adenine as a case-study. New J. Chem. 2013, 37, 2691-2699. [CrossRef]

23. De Duve, C. Vital Dust: Life as a Cosmic Imperative; Basic Books: New York, NY, USA, 1995.

24. Luisi, P.L.; Walde, P.; Oberholzer, T. Enzymatic RNA synthesis in self-reproducing vesicles: An approach to the construction of a minimal synthetic cell. Ber. Bunsenges. Phys. Chem. 1994, 98, 1160-1165. [CrossRef]

25. Adamala, K.; Szostak, J.W. Nonenzymatic Template-Directed RNA Synthesis Inside Model Protocells. Science 2013, 242, 1098-1100. [CrossRef] 
26. Powner, M.W.; Gerland, B.; Sutherland, J.D. Synthesis of activated pyrimidine ribonucleotides in prebiotically plausible conditions. Nature 2009, 459, 239-242. [CrossRef] [PubMed]

27. Patel, B.H.; Percivalle, C.; Ritson, D.J.; Duffy, C.D.; Sutherland, J.D. Common origins of RNA, protein, and lipid precursors in a cyanosulfidic protometabolism. Nat. Chem. 2015, 7, 301-307. [CrossRef] [PubMed] 